\title{
Biological treatment of selenium-laden wastewater containing nitrate and sulfate in an upflow anaerobic sludge bed reactor at $\mathrm{pH} 5.0$
}

\section{Authors: Lea Chua Tan, Yarlagadda V. Nancharaiah, Shipeng Lu, Eric D. van Hullebusch, Robin Gerlach, and Piet N.L. Lens}

NOTICE: this is the author's version of a work that was accepted for publication in Chemosphere. Changes resulting from the publishing process, such as peer review, editing, corrections, structural formatting, and other quality control mechanisms may not be reflected in this document. Changes may have been made to this work since it was submitted for publication. A definitive version was subsequently published in Chemosphere, VOL\# 211, (November 2018) DOI\#10.1016/ j.chemosphere.2018.07.079

Tan, Lea Chua, Yarlagadda V. Nancharaiah, Shipeng Lu, Eric D. van Hullebusch, Robin Gerlach, and Piet N.L. Lens. "Biological Treatment of Selenium-Laden Wastewater Containing Nitrate and Sulfate in an Upflow Anaerobic Sludge Bed Reactor at pH 5.0." Chemosphere 211 (November 2018): 684-693. doi:10.1016/j.chemosphere.2018.07.079. 


\title{
Biological treatment of selenium-laden wastewater containing nitrate and sulfate in an upflow anaerobic sludge bed reactor at $\mathrm{pH} 5.0$
}

\author{
Lea Chua Tan ${ }^{\mathrm{a}, *}$, Yarlagadda V. Nancharaiah ${ }^{\mathrm{b}}$, Shipeng Lu ${ }^{\mathrm{c}}$, Eric D. van Hullebusch ${ }^{\mathrm{a}, \mathrm{d}}$, \\ Robin Gerlach ${ }^{c}$, Piet.N.L. Lens ${ }^{\text {a, e }}$ \\ a UNESCO-IHE Institute for Water Education, Westvest 7, 2611 AX Delft, The Netherlands \\ ${ }^{\mathrm{b}}$ Biofouling and Biofilm Process Section, Water and Steam Chemistry Division, Bhabha Atomic Research Centre, Kalpakkam 603102, Tamil Nadu, India \\ ${ }^{c}$ Center for Biofilm Engineering, Montana State University, Bozeman, MT 59717, USA \\ d Université Paris-Est, Laboratoire Géomatériaux et Environnement (EA 4508), UPEM, 77454 Marne-la-Vallée, France \\ e Department of Chemistry and Bioengineering, Tampere University of Technology, P.O. Box 541, Tampere, Finland
}

G R A P H I C A L A B S T R A C T

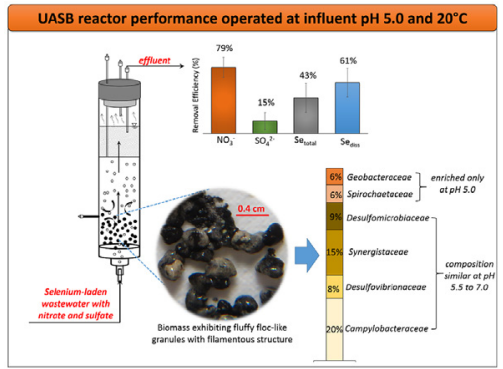

A B S T R A C T

This study investigated the removal of selenate $\left(\mathrm{SeO}_{4}^{2-}\right)$, sulfate $\left(\mathrm{SO}_{4}^{2-}\right)$ and nitrate $\left(\mathrm{NO}_{3}^{-}\right)$at different influent $\mathrm{pH}$ values ranging from 7.0 to 5.0 and $20^{\circ} \mathrm{C}$ in an upflow anaerobic sludge blanket (UASB) reactor using lactate as an electron donor. At pH 5.0, the UASB reactor showed a $20-30 \%$ decrease in reactor performance compared to operation at $\mathrm{pH} 5.5$ to 7.0 , reaching removal efficiencies of $79 \%, 15 \%, 43 \%$ and $61 \%$ for $\mathrm{NO}_{3}^{-}, \mathrm{SO}_{4}^{2-}, \mathrm{Se}_{\text {total }}$ and $\mathrm{Se}_{\text {diss, }}$, respectively. However, the reactor stability was an issue upon lowering the $\mathrm{pH}$ to 5.0 and further experiments are recommended. The sludge formed during low $\mathrm{pH}$ operation had a fluffy, floc-like appearance with filamentous structure, possibly due to the low polysaccharide (PS) to protein (PN) ratio (0.01 PS/PN) in the soluble extracellular polymeric substances (EPS) matrix of the biomass. Scanning electron microscopy with energy dispersive X-ray spectroscopy (SEMEDX) analysis of the sludge confirmed Se oxyanion reduction and deposition of $\mathrm{Se}^{0}$ particles inside the biomass. Microbial community analysis using Illumina MiSeq sequencing revealed that the families of Campylobacteraceae and Desulfomicrobiaceae were the dominant phylotypes throughout the reactor operation at approximately $23 \%$ and $10 \%$ relative abundance, respectively. Furthermore, approximately $10 \%$ relative abundance of both Geobacteraceae and Spirochaetaceae was observed in the granular sludge during the $\mathrm{pH} 5.0$ operation. Overall, this study demonstrated the feasibility of UASB operation at $\mathrm{pH}$ values ranging from 7.0 to 5.0 for removing Se and other oxyanions from wastewaters. 


\section{Introduction}

Selenium (Se) is both an essential and toxic trace element for living cells, with only 5- to 10 -fold difference between essential and toxic concentrations (Nancharaiah and Lens, 2015). Se accumulation and intoxication can cause mutations, reproductive failures and teratogenic effects, particularly with aquatic egg-laying organisms upon exposure to toxic Se levels (Lemly, 2014). As such, it is now widely recognized that removal of Se from contaminated waters is essential for the protection of animal, human and ecosystem health (Tan et al., 2016).

Compared to physical and chemical technologies, biological treatment has emerged in recent years as a promising Se removal technology due to the possibility of simultaneous treatment of various oxyanions as well as yielding elemental $\mathrm{Se}\left(\mathrm{Se}^{0}\right)$ nanoparticles that can potentially be recovered and reused (Tan et al., 2016). Despite these recent advances, there are still many challenges in applying this bioprocess to real wastewaters. One such challenge is the low $\mathrm{pH}$ of some Se-laden wastewaters, e.g. acid mine drainage (AMD) wastewater. AMD wastewater is characterized by low $\mathrm{pH}$ values (varying between $\mathrm{pH} 2$ to 5) and varying heavy metal concentrations depending on the mining site (Koschorreck and Tittel, 2007). Se speciation depends on pH, ionic strength and redox properties of a system (Erosa et al., 2009). Adjustment of the initial $\mathrm{pH}$ entails additional costs when the process is transferred into full-scale applications treating real wastewaters. Espinosa-Ortiz et al. (2015) reported selenite $\left(\mathrm{SeO}_{3}^{2-}\right)$ removal from $\mathrm{pH} 4.5$ medium using Phanerochaete chrysosporium fungal pellets and achieved a total soluble selenium $\left(\mathrm{SeO}_{3}^{2-}\right)$ removal efficiency of $70 \%$. However, the fungal pellets were incapable of reducing and removing selenate $\left(\mathrm{SeO}_{4}^{2-}\right)$.

Table 1 gives an overview of bioreactor studies related to the treatment of Se-laden wastewaters. It shows that there are very limited studies investigating the effect of $\mathrm{pH}$ on Se removal. The majority of the studies, as summarized in Table 1, adjusted the initial $\mathrm{pH}$ to a circum-neutral $\mathrm{pH}$ during laboratory testing or used a buffer medium before performing Se bioremoval to avoid large $\mathrm{pH}$ fluctuations and associated impact on the biological system. Therefore, bioprocesses capable of Se removal from wastewaters with low $\mathrm{pH}$ without prior neutralization need to be developed.

This study investigated the effect of decreasing influent $\mathrm{pH}$ (from 7.0 to $\mathrm{pH}$ 5.0) on the performance of a continuously operated upflow anaerobic sludge blanket (UASB) reactor (referred to as low $\mathrm{pH}$ reactor) treating $\mathrm{SeO}_{4}^{2-}, \mathrm{SO}_{4}^{2-}$ and $\mathrm{NO}_{3}^{-}$using anaerobic granular sludge at room temperature. The aim of the study was to observe the lowest possible influent $\mathrm{pH}$ at which the UASB can be operated for the removal of the targeted oxyanions. The protein, polysaccharide, and Se content of the UASB granules were determined at various time points and compared to the inoculum and granular sludge from a control UASB reactor operated at $\mathrm{pH}$ 7.0. Low $\mathrm{pH}$ reactor biomass morphology was also analyzed at the end of the reactor run and compared to inoculum and control reactor. The microbial community composition of the inoculum and sludge sampled from the low $\mathrm{pH}$ reactor was analyzed and related to low pH UASB reactor performance and operational strategies.

\section{Materials and methods}

\subsection{Source of biomass}

Experiments were performed with anaerobic granular sludge taken from a full-scale UASB reactor treating paper-mill wastewater in Eerbeek (The Netherlands). Biomass was supplied at $10 \mathrm{~g}$ (wet weight) to $100 \mathrm{~mL}$ medium as described in Lenz et al. (2008). No additional biomass was added during the entire reactor run. Prior to each operational change (see below), a small portion of the biomass was withdrawn from the UASB reactor for analysis of microbial community, protein and polysaccharide content.

\subsection{Synthetic wastewater}

All experiments were carried out using synthetic mining wastewater containing (in $\mathrm{g} \mathrm{L}^{-1}$ ): $\mathrm{NH}_{4} \mathrm{Cl}(0.30), \mathrm{CaCl}_{2} \cdot 2 \mathrm{H}_{2} \mathrm{O}(0.01)$, $\mathrm{MgCl}_{2} \cdot 6 \mathrm{H}_{2} \mathrm{O}(0.01)$, and $\mathrm{NaHCO}_{3}(0.04)$. Acid and alkaline trace

Table 1

Comparison of studies on Se removal in different bioreactors in the presence of co-oxyanions.

\begin{tabular}{|c|c|c|c|c|c|c|}
\hline Reactor type & $\mathrm{Se}_{\text {inf. }}$ & Other Ions & Inoculum & Operational Conditions & Removal Efficiency & References \\
\hline $\mathrm{H}_{2}-\mathrm{MBfR}$ & $\begin{array}{l}0.55 \mathrm{mg} \mathrm{SeO}_{4}^{2-}-\mathrm{Se} \\
\mathrm{L}^{-1}\end{array}$ & $\begin{array}{l}5 \mathrm{mg} \mathrm{NO}-\mathrm{N} \mathrm{L}^{-1} \\
79 \mathrm{mg} \mathrm{SO}_{4}^{2-} \mathrm{L}^{-1}\end{array}$ & $\begin{array}{l}\text { Biofilm from pilot plant } \\
\text { treating groundwater }\end{array}$ & $\mathrm{pH} 7.0-9.0 ; \mathrm{H}_{2}$ gas & $\begin{array}{l}90 \% \text { Se; } 100 \% \mathrm{NO}_{3}^{-} ; 75 \% \\
\mathrm{SO}_{4}^{2-}\end{array}$ & Chung et al. (2006) \\
\hline MBfR & $\begin{array}{l}0.55 \mathrm{mg} \mathrm{SeO}_{4}^{2-}-\mathrm{Se} \\
\mathrm{L}^{-1}\end{array}$ & $0-10 \mathrm{mg} \mathrm{NO}_{3}^{-}-\mathrm{N} \mathrm{L}^{-1}$ & $\begin{array}{l}\text { Denitrifying anaerobic } \\
\text { methane oxidation } \\
\text { (DAMO) culture }\end{array}$ & $\mathrm{pH} 7.0 ; 30^{\circ} \mathrm{C} ; \mathrm{CH}_{4}$ gas & $\begin{array}{l}94 \% \mathrm{SeO}_{4}^{2-} \text { (without } \\
\mathrm{NO}_{3}^{-} \text {); } 60-75 \% \mathrm{SeO}_{4}^{2} \\
75 \% \mathrm{NO}_{3}^{-}\end{array}$ & Lai et al. (2016) \\
\hline $\mathrm{H}_{2}-\mathrm{MBfR}$ & $\begin{array}{l}0.55-6.6 \mathrm{mg} \mathrm{SeO}_{4}^{2-}- \\
\mathrm{Se} \mathrm{L}^{-1}\end{array}$ & $40-90 \mathrm{mg} \mathrm{SO}_{4}^{2-} \mathrm{L}^{-1}$ & $\begin{array}{l}\text { Anoxic sludge from } \\
\text { wastewater treatment } \\
\text { plant }\end{array}$ & $\begin{array}{l}\text { pH 7.0-9.0; HRT } 3.3 \mathrm{~h} ; \\
20^{\circ} \mathrm{C} ; \mathrm{H}_{2} \text { gas }\end{array}$ & $>90 \% \mathrm{SeO}_{4}^{2-} ; 25 \% \mathrm{SO}_{4}^{2-}$ & $\begin{array}{l}\text { Ontiveros-Valencia } \\
\text { et al. (2016) }\end{array}$ \\
\hline $\begin{array}{l}\text { Upflow fungal } \\
\text { pelleted reactor }\end{array}$ & $\begin{array}{l}0.79 \mathrm{mg} \mathrm{SeO}_{3}^{2-}-\mathrm{Se} \\
\mathrm{L}^{-1}\end{array}$ & No co-contaminants & $\begin{array}{l}\text { Phanerochaete } \\
\text { chrysosporium }\end{array}$ & $\begin{array}{l}\mathrm{pH} 4.5 \text {; HRT } 24 \mathrm{~h} ; 30^{\circ} \mathrm{C} \text {; } \\
\text { Glucose }\end{array}$ & $70 \% \mathrm{SeO}_{3}^{2-}$ & $\begin{array}{l}\text { Espinosa-Ortiz et al. } \\
\text { (2015) }\end{array}$ \\
\hline UASB & $\begin{array}{l}0.79 \mathrm{mg} \mathrm{SeO}{ }_{4}^{2-}-\mathrm{Se} \\
\mathrm{L}^{-1}\end{array}$ & $<2500 \mathrm{mg} \mathrm{SO}_{4}^{2-} \mathrm{L}^{-1}$ & $\begin{array}{l}\text { Eerbeek anaerobic } \\
\text { granular sludge }\end{array}$ & $\begin{array}{l}\mathrm{pH} 7.0 ; \mathrm{HRT} 6 \mathrm{~h} ; 30^{\circ} \mathrm{C} \text {; } \\
\text { lactate }\end{array}$ & $\begin{array}{l}99 \% \mathrm{Se} \text { (methanogenic } \\
\text { condition); } 97 \%\left(\mathrm{SO}_{4}^{2-}\right. \\
\text { reducing condition); } 20 \\
-90 \% \mathrm{SO}_{4}^{2-}\end{array}$ & Lenz et al. (2008) \\
\hline UASB & $\begin{array}{l}0.79 \mathrm{mg} \mathrm{SeO}{ }_{4}^{2-}-\mathrm{Se} \\
\mathrm{L}^{-1}\end{array}$ & $\begin{array}{l}930 \mathrm{mg} \mathrm{NO}_{3}^{-}-\mathrm{N} \mathrm{L}^{-1} \\
192 \mathrm{mg} \mathrm{SO}_{4}^{2-} \mathrm{L}^{-1}\end{array}$ & $\begin{array}{l}\text { Eerbeek anaerobic } \\
\text { granular sludge with } \\
\text { immobilized } \\
\text { Sulfurospirillum barnesii }\end{array}$ & $\begin{array}{l}\mathrm{pH} 7.0 \text {; HRT } 6 \mathrm{~h} ; 30^{\circ} \mathrm{C} \text {; } \\
\text { lactate }\end{array}$ & $\begin{array}{l}97 \% \text { Se; } 100 \% \mathrm{NO}_{3}^{-} ; 90 \% \\
\mathrm{SO}_{4}^{2-} \text { (after } \mathrm{NO}_{3}^{-} \text {had } \\
\text { been removed) }\end{array}$ & Lenz et al. (2009) \\
\hline UASB & $13 \mathrm{mg} \mathrm{Se} \mathrm{\textrm {L } ^ { - 1 }}$ & $\begin{array}{l}1-10 \mathrm{~g} \mathrm{~L}^{-1} \\
\text { heavy metals } \\
35.6 \mathrm{~S} \mathrm{~g} \mathrm{~L}^{-1}\end{array}$ & $\begin{array}{l}\text { Anaerobic sludge from } \\
\text { mesophilic UASB } \\
\text { reactor treating } \\
\text { beverage wastewater }\end{array}$ & $\begin{array}{l}\mathrm{pH}<1.0 \text { adjusted to } 6.0 \\
-9.0 ; \mathrm{HRT} 24 \mathrm{~h} ; 30^{\circ} \mathrm{C} \text {; } \\
\text { ethanol }\end{array}$ & $97 \% \mathrm{Se}_{\text {total }}$ & Soda et al. (2011) \\
\hline UASB & $\begin{array}{l}5-12 \mathrm{mg} \mathrm{SeO}_{4}^{2-}-\mathrm{Se} \\
\mathrm{L}^{-1}\end{array}$ & $\begin{array}{l}47 \mathrm{mg} \mathrm{NO}--\mathrm{N} \mathrm{L}^{-1} \\
1500 \mathrm{mg} \mathrm{SO}_{4}^{2-} \mathrm{L}^{-1}\end{array}$ & $\begin{array}{l}\text { Eerbeek anaerobic } \\
\text { granular sludge }\end{array}$ & $\begin{array}{l}\text { pH 5.0-7.0; HRT } 24 \mathrm{~h} \text {; } \\
20^{\circ} \mathrm{C} \text {; lactate }\end{array}$ & $\begin{array}{l}43 \% \mathrm{Se}_{\mathrm{total}} ; 61 \% \mathrm{Se}_{\mathrm{diss}} \\
85 \% \mathrm{SeO}_{3}^{2-} ; 92 \% \mathrm{NO}_{3}^{-} \\
15 \% \mathrm{SO}_{4}^{2-}\end{array}$ & This study \\
\hline
\end{tabular}

${ }^{*} \mathrm{H}_{2}$-MBfR - hydrogen-based membrane biofilm reactors; UASB - upflow anaerobic sludge bed. 
metal solutions $(0.1 \mathrm{~mL}$ each) were added to $1 \mathrm{~L}$ of synthetic wastewater (composition of trace metal solutions is described in Stams et al., 1992). No phosphate or pH buffer was included in the medium and the $\mathrm{pH}$ was adjusted to the desired $\mathrm{pH}$ using $0.5 \mathrm{M}$ $\mathrm{HCl}$. Analytical grade sodium lactate was used as the electron donor and potassium nitrate, potassium sulfate and sodium selenate were added as electron acceptors. Their concentrations depended on the operational period, as described below.

\subsection{UASB reactor}

\subsubsection{Low $\mathrm{pH}$ bioreactor configuration and operating conditions}

The low pH UASB reactor had a working volume of $2.0 \mathrm{~L}$, an inner diameter of $5.6 \mathrm{~cm}$ and a length of $1 \mathrm{~m}$ (Fig. S1). It was operated at room temperature $\left(20 \pm 2{ }^{\circ} \mathrm{C}\right)$ at an average hydraulic residence time (HRT) of $24 \mathrm{~h}$. The influent flow rate was set at $1.4 \mathrm{~mL} \mathrm{~min}^{-1}$ and the upflow velocity at $1.5 \mathrm{~m} \mathrm{~h}^{-1}$ with a recirculation flow of $62 \mathrm{~mL} \mathrm{~min}^{-1}$. The organic loading rate was $2 \mathrm{~g}$ COD $\mathrm{L}^{-1} \mathrm{~d}^{-1}$ using lactate as the electron donor.

The low $\mathrm{pH}$ UASB reactor was provided with excess electron donor and exposed to three oxyanions, i.e. $\mathrm{SeO}_{4}^{2-}, \mathrm{NO}_{3}^{-}$and $\mathrm{SO}_{4}^{2-}$, for the entire duration of the study. An average of $48( \pm 5) \mathrm{mg} \mathrm{NO}_{3}^{-}-\mathrm{N}$ $\mathrm{L}^{-1}$ and $2( \pm 0.5) \mathrm{g} \mathrm{SO}_{4}^{2-} \mathrm{L}^{-1}$ were fed into the low $\mathrm{pH}$ reactor for the entire UASB reactor operation. The low pH UASB reactor was operated in three different operational periods (Phase I to III). The first phase of the low $\mathrm{pH}$ reactor operation was divided into 5 parts. Phase Ia used approximately $10 \mathrm{mg} \mathrm{Se}^{-1}$ as $\mathrm{SeO}_{4}^{2-}, 42 \mathrm{mg} \mathrm{NO}_{3}^{-}-\mathrm{N}$ $\mathrm{L}^{-1}$ and $2 \mathrm{~g} \mathrm{SO}_{4}^{2-} \mathrm{L}^{-1}$ at $\mathrm{pH} 7.0$ and was considered the start-up phase, lasting for 29 days. Subsequent phases were maintained long enough to reach a pseudo-steady-state. The influent $\mathrm{pH}$ was gradually decreased from $\mathrm{pH} 7.0$ (phase $\mathrm{Ib}$, day 30-61) to $\mathrm{pH} 6.0$ (phase Ic, day 62-90), to pH 5.5 (phase Id, day 91-129) and finally to $\mathrm{pH} 5.0$ (phase Ie, day 130-168). Each phase was operated for approximately 32 days before the $\mathrm{pH}$ was changed. After phase Ie, the incoming feed $\mathrm{pH}$ was maintained at $\mathrm{pH} 5.0$ and the removal efficiency stability of the bioreactor was assessed by changing the $\mathrm{SeO}_{4}^{2-}$ concentration from $\sim 12 \mathrm{mg} \mathrm{Se}^{-1}$ (phase I) to a range of 1-5 $\mathrm{mg} \mathrm{Se} \mathrm{L}^{-1}$ (phase Ila, day 169-202) and then back to $12 \mathrm{mg} \mathrm{Se}$ $\mathrm{L}^{-1}$ (phase IIb, day 203-231). Finally, the effect of $\mathrm{SeO}_{3}^{2-}$ addition at pH 5.0 was investigated during phase III (day 232-266), where the total Se concentration $\left(\sim 10 \mathrm{mg} \mathrm{Se}^{-1}\right)$ in the influent consisted of $50 \% \mathrm{SeO}_{3}^{2-}$ and $50 \% \mathrm{SeO}_{4}^{2-}$. The average influent Se concentrations (as $\mathrm{SeO}_{4}^{2-}$ ) during phase I was $12.0( \pm 0.8) \mathrm{mg} \mathrm{Se} \mathrm{L}^{-1} \mathrm{~d}^{-1}, 3.0( \pm 0.8)$

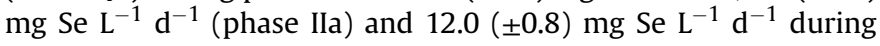
phase IIb. In phase III, the concentration of total Se was split into $50 \% \mathrm{SeO}_{4}^{2-}$ and $50 \% \mathrm{SeO}_{3}^{2-}$ in $\mathrm{mg} \mathrm{Se}^{-1}$ at a concentration of 5.0 $( \pm 1.0) \mathrm{mg} \mathrm{Se} \mathrm{L}^{-1}$ and $4.0( \pm 0.5) \mathrm{mg} \mathrm{Se} \mathrm{L}^{-1}$, respectively. Pseudosteady state was considered for each phase once there were seven consecutive data points observed within $\pm 10 \%$ relative error to each other.

\subsubsection{Control reactor set-up}

A control reactor was operated alongside the low $\mathrm{pH}$ reactor with an influent stream $\mathrm{pH}$ of 7.0. The control reactor set-up was operated similarly to phases la and Ib of the low $\mathrm{pH}$ reactor with phase I of the control reactor ( $\mathrm{pH} 7.0$ ) which only lasted for 92 days. The sludge characteristics of the control reactor (i.e. polysaccharide/protein ratio and biomass morphology) were reported and compared with sludge characteristics of the low $\mathrm{pH}$ reactor.

\subsubsection{Analytical methods}

Liquid samples were collected and centrifuged at $37,000 \mathrm{~g}$ for $15 \mathrm{~min}$ to remove suspended cells and $\mathrm{Se}^{0}$ particles (Jain et al., 2015) before the supernatant was used for analysis. Chemical oxygen demand (COD), total dissolved sulfide (TDS), and total solids
(TS) measurements were carried out using standard methods (APHA, 2005). Ion chromatography (IC, Dionex ICS 1000 AS4A column) was used to measure the concentration of $\mathrm{NO}_{3}^{-}$and $\mathrm{SO}_{4}^{2-}$ at retention times of 3.9 and $7.5 \mathrm{~min}$, respectively. Due to $\mathrm{SO}_{4}^{2-}$ peak interference with the $\mathrm{SeO}_{4}^{2-}$ peak, $\mathrm{SeO}_{4}^{2-}$ was not determined by IC. Instead, all influent and effluent Se concentrations were analyzed as Se using a graphite furnace atomic absorption spectrometer (GFAAS, ThermoElemental Solaar MQZe GF95, Se lamp at $196.0 \mathrm{~nm}$ ) and reported as total Se $\left(\mathrm{Se}_{\text {total }}\right)$ and dissolved $\mathrm{Se}\left(\mathrm{Se}_{\text {diss }}\right)$. Se $\mathrm{Setal}_{\text {tot }}$ includes both dissolved Se and colloidal Se present in the collected liquid sample, while $\mathrm{Se}_{\text {diss }}$ includes only dissolved Se remaining in the effluent after centrifugation $(37,000 \mathrm{~g})$ and filtration $(0.45 \mu \mathrm{m}$, acetate membrane, Sigma-Aldrich, USA). The $\mathrm{SeO}_{3}^{2-}$ concentration in the reactor was measured using a spectrophotometric method as described by Li et al. (2014).

\subsubsection{Statistical analysis}

Averages and standard deviations were calculated for the oxyanion removal efficiencies. Statistical differences in lactate, $\mathrm{NO}_{3}^{-}$, $\mathrm{SO}_{4}^{2-}, \mathrm{Se}_{\text {total }}$ and $\mathrm{Se}_{\text {diss }}$ removal efficiencies between the low $\mathrm{pH}$ reactor operation phases were evaluated using analysis of variance (ANOVA) with Tukey tests, where a P-value $\leq 0.05$ was considered statistically significant. Minitab 17 Statistical (Minitab Inc., US) and OriginPro 9.0 (OriginLab Corporation, US) software were used for statistical analysis and for presenting results in the form of graphs, respectively.

\subsection{Anaerobic granular sludge characterization}

\subsubsection{Microbial community analysis}

Granular sludge samples from the UASB reactor at the end of each period and from the inoculum were analyzed for microbial community composition. Prior to sampling, vigorous biomass mixing within the reactor was performed by briefly increasing the upflow velocity. Genomic DNA was extracted from the samples following the protocol of Lueders et al. (2004). Extracted DNA was quantified using a NanoDrop-1000 spectrophotometer and amplified by PCR using the primers Pro 341 forward and Pro 805 reverse targeting the V4 region of the 16S rRNA gene of bacteria and archaea (Takahashi et al., 2014). Amplicons were checked by agarose gel electrophoresis and sequenced using the Illumina MiSeq sequencing platform following the standard protocol. Sequences produced were analyzed using the standard operating procedure of the bioinformatics platform Mothur (Schloss et al., 2009).

\subsubsection{Protein, polysaccharide and selenium content}

On days 168 (end of phase Ie) and 266 (end of phase III), granular sludge was taken from low $\mathrm{pH}$ reactor for analysis of protein, polysaccharide and Se content. Liquid suspension with biomass $(100 \mathrm{~mL})$ was taken and the granular sludge was homogenized using a glass potter homogenizer. Protein and polysaccharide concentrations were determined after extracting soluble extracellular polymeric substances (EPS) following the protocol of Geyik and Çeçen (2014). Briefly, a known weight of sludge was homogenized using a potter homogenizer and centrifuged at $12,000 \mathrm{~g}$ for $10 \mathrm{~min}$. The supernatant was considered the 1st soluble EPS fraction. The pellet was re-suspended in PBS and centrifuged again at $12,000 \mathrm{~g}$ for $10 \mathrm{~min}$. This supernatant was taken as the 2 nd soluble EPS fraction. The two EPS fractions were pooled, filtered using a $0.45 \mu \mathrm{m}$ membrane and stored at $-20^{\circ} \mathrm{C}$ until analysis.

Analyses of protein and polysaccharide content were carried out using the Pierce ${ }^{\mathrm{TM}}$ BSA protein assay kit (ThermoScientific) and phenol-sulfuric acid method (Albalasmeh et al., 2013), respectively. The total Se in the granular sludge was measured after acid 
digestion with $65 \% \mathrm{HNO}_{3}$ (MARS 5 pKo Temp CEM Microwave) using GFAAS.

The morphology of granular sludge from the inoculum, control reactor and low $\mathrm{pH}$ reactor was determined using stereomicroscopy and scanning electron microscopy (SEM, Zeiss Supra ${ }^{\mathrm{TM}}$ 55VP) equipped with energy dispersive X-ray spectroscopy (EDX, Princeton Gamma-Tech). EDX was used for detection of Se and S on the surface of the granular sludge. For SEM-EDX analysis, the sludge samples were prepared by gentle rinsing with Milli-Q water $\left(18 \mathrm{M} \Omega \mathrm{cm}^{-1}\right)$ and leaving them to dry on a dish at ambient temperature. Dried samples were deposited on carbon tape and coated with iridium before imaging.

\section{Results}

\subsection{Low $\mathrm{pH}$ reactor performance at decreasing $\mathrm{pH}$}

The low $\mathrm{pH}$ reactor performance in terms of $\mathrm{COD}, \mathrm{NO}_{3}^{-}, \mathrm{SO}_{4}^{2-}$ and Se removal efficiencies is shown in Fig. 1, while the averaged effluent concentrations are reported in Table S1. Statistical groupings of the different phases during the low $\mathrm{pH}$ reactor operation were developed for comparison of the removal performances (Table S2). Phases that did not exhibit statistically significantly different removal efficiencies were grouped together. The $\mathrm{pH}$ of the feed was gradually lowered from 7.0 to 5.0 to avoid a sudden $\mathrm{pH}$ shock on the biomass. Although the influent $\mathrm{pH}$ was lowered from 7.0 to 5.0 , the effluent $\mathrm{pH}$ values were always between $\mathrm{pH} 7$ and 8 , with an average $\mathrm{pH}$ of $7.4( \pm 0.3)$.

The low $\mathrm{pH}$ reactor demonstrated relatively stable $\mathrm{COD}, \mathrm{NO}_{3}^{-}$ and Se removal for influent $\mathrm{pH}$ values between 7 and 5.5. The COD removal efficiency was, on average, $74( \pm 3) \%$ from start-up until the end of phase Id. However, the COD removal efficiency diminished to $58( \pm 9) \%$ when the influent $\mathrm{pH}$ was decreased to 5.0 in phase Ie $(P$ value $\leq 0.0001$ ). The $\mathrm{NO}_{3}^{-}$removal efficiency during phase Ia to Ic (influent pH 7.0 to 6.0$)$ was on average $97( \pm 2) \%$ and decreased slightly to $90( \pm 3) \%$ during phases Id and Ie (influent pH 5.5 and 5.0). Overall, $\mathrm{NO}_{3}^{-}$removal efficiencies were not statistically significantly different during phases la through le at an average of $94( \pm 5) \%(0.30 \leq P$-value $\leq 0.52) . \mathrm{SO}_{4}^{2-}$ removal, on the other hand, increased from $14( \pm 9) \%$ in phase la to an average of $42( \pm 8) \%$ during phases Ib-Id (influent pH 7.0 to $5.5, P$-value $\leq 0.0001$ ), but decreased again to $14( \pm 9) \%$ in phase Ie (influent $\mathrm{pH} 5.0, P$ value $\leq 0.0001$ ). The sulfide concentrations in the effluent were initially at $70( \pm 9) \mathrm{mg}$ TDS L ${ }^{-1}$, increased to $359( \pm 137) \mathrm{mg} \mathrm{TDS} \mathrm{L}^{-1}$ during phases Ib-Id and then exhibited a sudden decrease to 83 $( \pm 34) \mathrm{mg} \mathrm{TDS} \mathrm{L}^{-1}$.

$\mathrm{Se}_{\text {total }}$ removal followed a similar trend from phase Ib until halfway through phase Id with high removal efficiencies of 91 $( \pm 6) \%, 91( \pm 5) \%, 84( \pm 6) \%, 78( \pm 14) \% S_{\text {total }}$, for phases Ia-d, respectively. $\mathrm{Se}_{\text {total }}$ removal efficiencies were not statistically significantly different during phases Ia to Id $(0.45 \leq P$-value $\leq 1.0)$ at an average of $88( \pm 7) \%$ but decreased to $43( \pm 13) \%$ for phase Ie $(P$ value $\leq 0.003)$. $\mathrm{Se}_{\mathrm{diss}}$ removal efficiencies exhibited a similar trend to the $\mathrm{Se}_{\text {total }}$ removal efficiencies, showing good removal at 95 $( \pm 3) \%$ from start-up to halfway into phase Id. During phase Id (day 113-121), the reactor continuous operation had to be stopped for approximately one week due to maintenance needs such as replacement of tubing. Mixing was still maintained by providing an internal recirculation (from the biomass sampling port to the effluent port, Fig. S1) to maintain biomass activity. Due to the internal circulation arrangement, only a small portion of the sludge was not properly mixed during maintenance. This could have caused the temporary decrease in reactor performance during the end of phase Id which appeared to have recovered within a few days. During phase Ie (operated at pH 5.0), the removal efficiency of $\mathrm{Se}_{\text {diss }}$ decreased to $61( \pm 17) \%$. The activity test of the biomass taken during phase Ie (Fig. S2) indicated that the biomass still had the potential to be highly metabolically active.

Removal performance results for the control reactor over 92 days are shown in Fig. S3 and were found to not be statistically different from the low $\mathrm{pH}$ reactor (Table $\mathrm{S} 2$ ) for $\mathrm{COD}, \mathrm{NO}_{3}^{-}, \mathrm{SO}_{4}^{2-}$ and Se removal during phases la to Id.

\subsection{Low $\mathrm{pH}$ reactor performance with changing Se concentration}

The COD removal efficiency decreased from $58( \pm 9) \%$ from phase le to an average of $43( \pm 5) \%$ during phase II and finally to 20 $( \pm 9) \%$ when $\mathrm{SeO}_{3}^{2-}$ was added to the low $\mathrm{pH}$ reactor (phase III, $P$ value $\leq 0.0001$ ). Similarly, the low $\mathrm{pH}$ reactor showed an overall $20 \%$ decrease in $\mathrm{NO}_{3}^{-}$removal efficiency after phase Ie $(P$ value $\leq 0.01$ ), while the $\mathrm{SO}_{4}^{2-}$ removal performance was fairly consistent at an average of $13( \pm 4) \%$, similar to phase Ie $(0.52 \leq P$ value $\leq 1.0)$. Sulfide concentrations in the effluent consistently decreased during each phase, reaching a concentration of $8( \pm 6) \mathrm{mg}$ TDS $\mathrm{L}^{-1}$ at the end of the reactor run. Phase II and phase III attained a Se removal performance comparable to the one in phase Ie $(0.13 \leq P$-value $\leq 0.95)$, calculating an average $\mathrm{Se}_{\text {total }}$ and $\mathrm{Se}_{\mathrm{diss}}$ removal efficiency of $40( \pm 18) \%$ and $60( \pm 14) \%$, respectively. A $\mathrm{SeO}_{3}^{2-}$ removal efficiency of $85( \pm 6) \%$ was achieved during phase III.

\subsection{Granular sludge characterization}

During the beginning of phase Ie, floating biomass was frequently observed in the low $\mathrm{pH}$ reactor as depicted in Fig. S4a, while no floating biomass was observed in the control reactor (Fig. S4b). However, starting with phase IIb until the end of the low $\mathrm{pH}$ reactor run, floating biomass was rarely observed. The sludge from the control reactor retained its granular shape with red particles deposited on the surface (Fig. 2 b1). In contrast, the biomass from the low $\mathrm{pH}$ reactor became fluffier with yellowish/reddish particles deposited on the surface (Fig. 2 c1).

The total Se concentration in the low $\mathrm{pH}$ reactor biomass at the end of phase Ie (day 168) was lower than in the control reactor biomass (Table 2). However, the Se concentrations increased by the end of phase III (day 266), indicating that the biomass was still capable of accumulating additional Se. SEM images (Fig. 2 b2 and c2) and EDX spectra (Fig. 2 b3 and c3) indicated that the biomass from both reactors formed $\mathrm{Se}^{0}$ within the granules. Spherical as well as a few rod-shaped $\mathrm{Se}^{0}$ structures were observed within the low $\mathrm{pH}$ reactor biomass, similar to $\mathrm{Se}^{0}$ spheres observed in other studies at neutral pH (Jain et al., 2015; Oremland et al., 2004).

The soluble EPS protein content from the low $\mathrm{pH}$ reactor biomass at the end of phase Ie (Table 2) was significantly higher at $432( \pm 17) \mathrm{mg}$ protein $\mathrm{g} \mathrm{TS}^{-1}(P$-value $\leq 0.001)$ compared to the inoculum and control reactor at $153( \pm 2)$ and $80( \pm 4) \mathrm{mg}$ protein $\mathrm{g}$ $\mathrm{TS}^{-1}$, respectively. In contrast, the soluble EPS polysaccharide concentration of the low $\mathrm{pH}$ reactor biomass during phase Ie was the lowest at $6( \pm 2) \mathrm{mg}$ polysaccharide $\mathrm{g} \mathrm{TS}^{-1}(P$-value $\leq 0.009)$. At the end of phase III (day 266), the soluble EPS protein content of the low $\mathrm{pH}$ reactor biomass had decreased considerably $(P$ value $\leq 0.0001)$, while the polysaccharide concentration had increased $(P$-value $\leq 0.002)$ as shown in Table 2.

\subsection{Microbial community analysis}

The microbial composition of the inoculum and with each change in reactor operation are reported as prokaryotic relative abundance at the family-level (Fig. 3). The inoculum was 


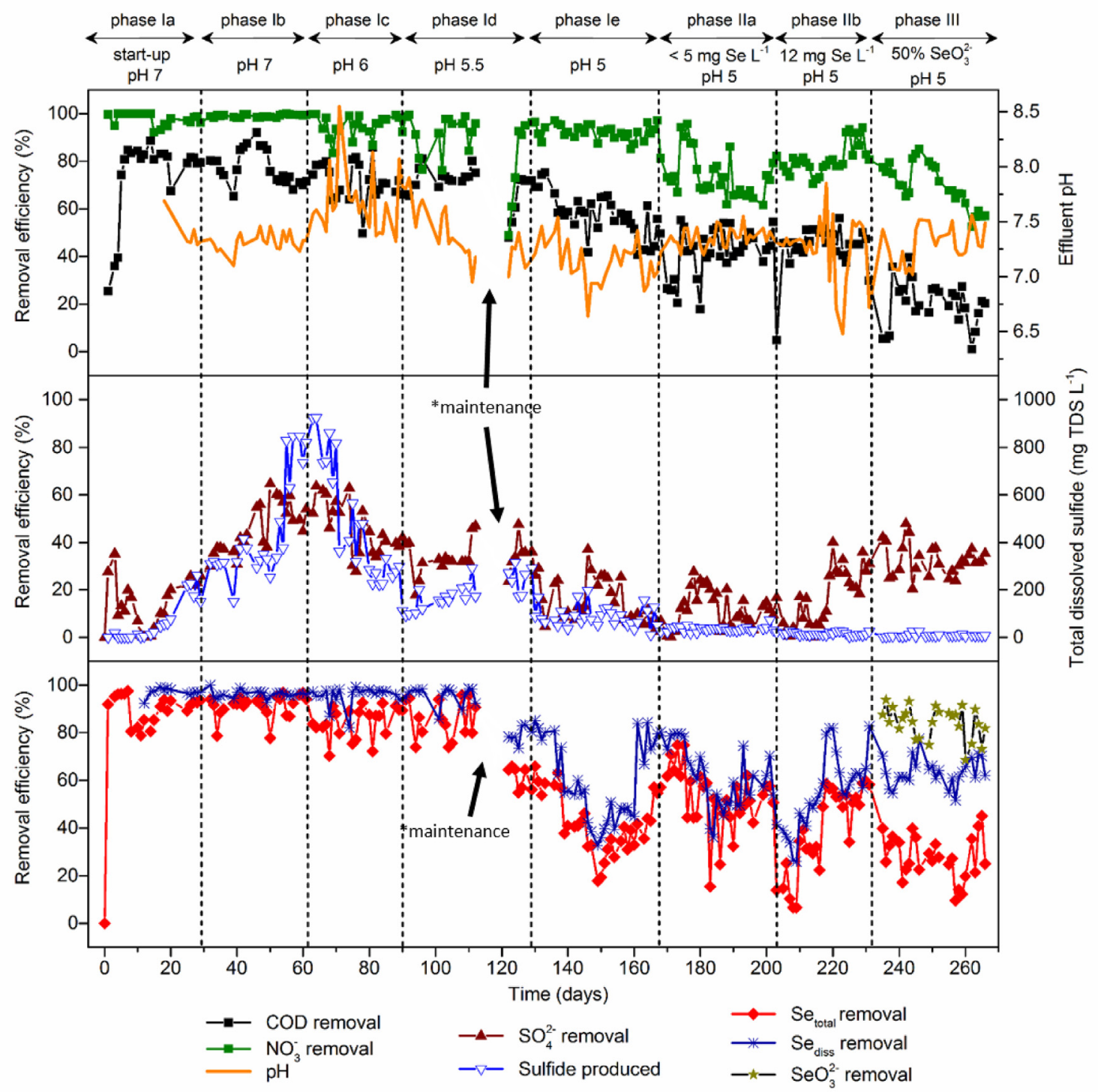

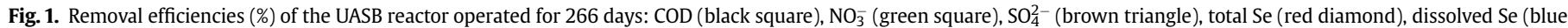

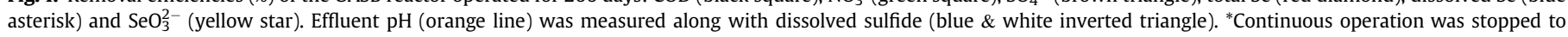

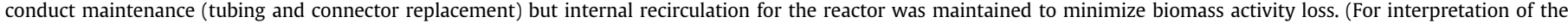
references to colour in this figure legend, the reader is referred to the Web version of this article.)

dominated by archaea such as the Methanosaetaceae (19.1\%) and Methanobacteriaceae (18.3\%); the most abundant bacterial groups were Anaerolineaceae (11.4\%) and Syntrophobacteraceae (8.7\%). A major change in microbial community was observed between the inoculum and the low $\mathrm{pH}$ reactor biomass samples due to a change of the relative archaeal abundance from $39 \%$ to $5 \%$. A shift in bacterial diversity was noticed within the low pH reactor biomass samples, but to a lesser extent than between the inoculum and low $\mathrm{pH}$ reactor samples.

The proteobacterial families Campylobacteraceae and Desulfomicrobiaceae were enriched in the reactor relative to the inoculum and changed from non-detectable to relative abundances of $34.4 \%$ and $20.2 \%$, respectively. The Synergistaceae and Desulfovibrionaceae increased from $6.9 \%$ and $3.4 \%$ (phase Id) to an average of $13( \pm 4) \%$ and $8( \pm 2) \%$, respectively, from phase Ie to III. Spirochaetaceae and Geobacteraceae started appearing during phase le (at pH 5.0) and their abundance increased until the end of phase III (Fig. 3).

\section{Discussion}

\subsection{Selenium bioremoval at low $\mathrm{pH}$}

This study, to our knowledge, is the first to investigate Se removal performance in a laboratory-scale UASB reactor treating a wastewater close to a real acid mine drainage: influent $\mathrm{pH}$ values as low as $\mathrm{pH} 5$, the presence of co-electron acceptors (i.e. $\mathrm{NO}_{3}^{-}$and $\left.\mathrm{SO}_{4}^{2-}\right)$ and ambient temperature $\left(20^{\circ} \mathrm{C}\right)$. The Se removal efficiencies obtained at an influent $\mathrm{pH}$ value of 5.0 showed a trend of approximately 20-30\% decrease in reactor performance reaching 43 $( \pm 13) \% \mathrm{Se}_{\text {total }}$ and $61( \pm 17) \% \mathrm{Se}_{\text {diss }}$ removal efficiencies compared to operation at pH 5.5 to 7.0. However, it was noted that the reactor stability was an issue after phase Ie. Though there was an observed trend of $20-30 \%$ decrease in performance due to the instability of the reactor, further experiments are required to establish the longterm reactor performance at low $\mathrm{pH}$ operation for Se removal in the 


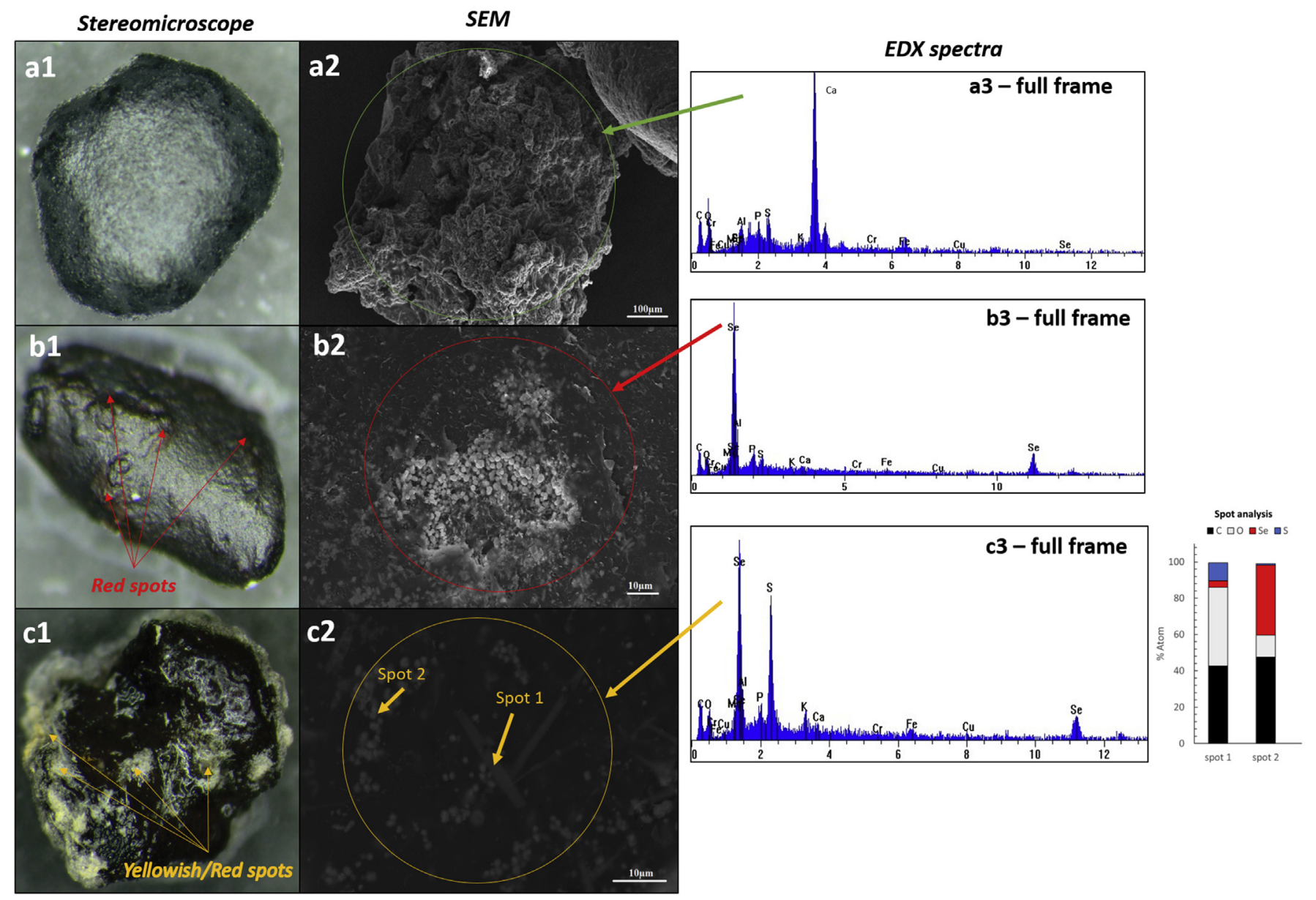

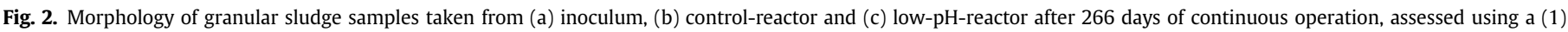
stereomicroscope and (2) SEM with full frame and spot-based elemental analysis at $20 \mathrm{kV}$; (3) representative EDX spectra of selected region.

Table 2

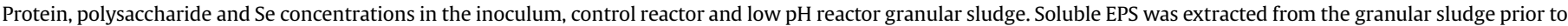
quantification of protein and polysaccharides while Se content in the biomass was determined after combined acid-heat digestion.

\begin{tabular}{|c|c|c|c|c|}
\hline Granular sludge & Inoculum & Control reactor $(\mathrm{pH} 7.0)$ & Low $\mathrm{pH}$ reactor $(\mathrm{pH} 5.0)$ & \\
\hline Conditions & Untreated (day 0) & $\begin{array}{l}\mathrm{NO}_{3}^{-}+\mathrm{SO}_{4}^{2-}+\mathrm{SeO}_{4}^{2-} \\
\text { (day 92) }\end{array}$ & $\begin{array}{l}\mathrm{NO}_{3}^{-}+\mathrm{SO}_{4}^{2-}+\mathrm{SeO}_{4}^{2-} \\
\text { (day } 168, \text { phase Ie) }\end{array}$ & $\begin{array}{l}\text { Addition of } 50 \% \mathrm{SeO}_{3}^{2-} \\
\text { (day 266, phase III) }\end{array}$ \\
\hline Protein (mg g TS $\left.{ }^{-1}\right)$ & $153.00( \pm 2.00)$ & $80.00( \pm 4.00)$ & $432.00( \pm 17.00)$ & $128( \pm 6.00)$ \\
\hline Polysaccharide (mg g TS${ }^{-1}$ ) & $31.00( \pm 2.00)$ & $17.00( \pm 2.00)$ & $6.00( \pm 2.00)$ & $52( \pm 19.00)$ \\
\hline Polysaccharide/Protein (PS/PN) & $0.20( \pm 0.06)$ & $0.20( \pm 0.06)$ & $0.01( \pm 0.01)$ & $0.4( \pm 0.20)$ \\
\hline Total Se in biomass (mg Se $\mathrm{g} \mathrm{TS}^{-1}$ ) & 0.00 & $45( \pm 6.00)$ & $12( \pm 1.00)$ & $86( \pm 12.00)$ \\
\hline
\end{tabular}

presence of co-electron acceptors.

It should be noted that other studies pre-conditioned the system for optimal performance at neutral $\mathrm{pH}$ and mesophilic conditions. Dessì et al. (2016) showed that the Se removal efficiency and Se retention within the biomass were greater at higher temperatures $\left(55^{\circ} \mathrm{C}\right)$, presumably due to the increase in crystallinity size, change in particle shape and decrease in zeta-potential of the biogenic $\mathrm{Se}^{0}$, allowing for better settleability and lowering the release of colloidal Se (Jain et al., 2017). Additionally, most of the previous studies did not consider the presence of co-electron acceptors, which can result in an added stress with regards to Se removal, e.g. competition or hindrance of bioreduction and toxicity. A study by Soda et al. (2011) used real Se wastewater taken from a Se refinery plant to evaluate biological Se reduction using a UASB reactor. The authors pre-conditioned the wastewater to increase the $\mathrm{pH}$ from
$<1.0$ to $6-9$ and to decrease salinity from $7 \%$ to $1 \%$ before feeding the wastewater into the biological treatment system. With this pretreatment approach, Soda et al. (2011) achieved $>90 \%$ Se removal in the biological system regardless of the presence of various heavy metals $\left(<5 \mathrm{mg} \mathrm{L}^{-1}\right)$.

Espinosa-Ortiz et al. (2015) demonstrated $70 \% \mathrm{SeO}_{3}^{2-}$ removal using pure culture fungal pellets at $\mathrm{pH} 4.5$ under aerobic conditions and immobilization of biogenic $\mathrm{Se}^{0}$ within the fungal pellets. However, compared to $\mathrm{SeO}_{4}^{2-}, \mathrm{SeO}_{3}^{2-}$ is highly reactive and readily reduced to $\mathrm{Se}^{0}$ by a number of microorganisms (Nancharaiah and Lens, 2015). Both low pH studies by Espinosa-Ortiz et al. (2015) and Kenward et al. (2006) employed pure cultures and as such, contamination becomes a concern when scaling-up. Concerns about contamination are largely eliminated when using mixed culture-based wastewater treatment systems, such as granular 


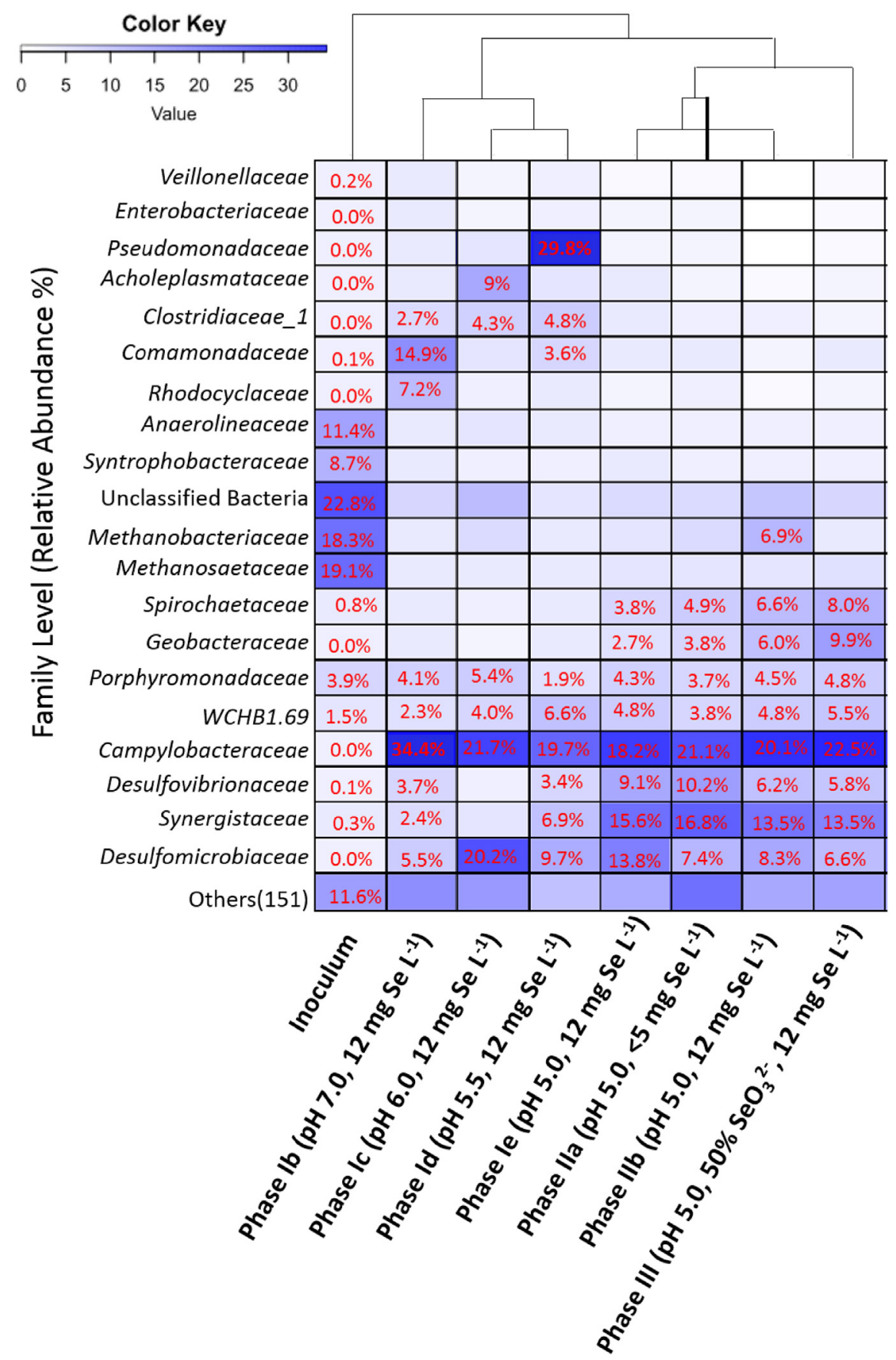

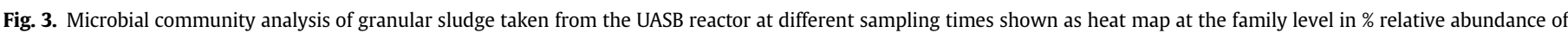

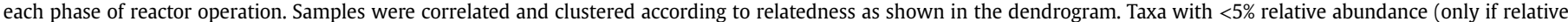
abundance are $<5 \%$ for all samples) were grouped together as "others" for all samples.

sludge as in this study. In any industrial operation, the stability of an anaerobic process is a key factor when scaling-up a system (Aslanzadeh et al., 2013). Long-term re-use and biosorption capacity of both fungal pellets and pure bacteria culture in a continuous bioreactor under low $\mathrm{pH}$ operation have yet to be established. In contrast to the previously mentioned studies, the UASB reactor used in this study was operated for a total of 176 days at pH 5.0 and managed to maintain a consistent Se removal efficiency (40\% Se $\mathrm{e}_{\text {total }}$ and $\left.60 \% \mathrm{Se}_{\mathrm{diss}}\right)$. Furthermore, the bioreactor was able to adapt quickly to operational changes and no irreversible toxicity to the granular sludge occurred due to the presence of $\mathrm{SeO}_{3}^{2-}$ at the low concentrations tested $\left(4 \pm 0.5 \mathrm{mg} \mathrm{Se} \mathrm{L}^{-1}\right)$. In contrast, Jain et al. (2016) observed $\mathrm{SeO}_{3}^{2-}$ toxicity to the activated sludge under aerobic conditions leading to repeated reactor crashes and failure in continuous operation.

The specific Se removal mechanisms in the presence of both $\mathrm{NO}_{3}^{-}$and $\mathrm{SO}_{4}^{2-}$ at low $\mathrm{pH}$ are largely unknown. Se oxyanion reduction to $\mathrm{Se}^{0}$ can be facilitated by dissimilatory metal reduction or unspecific detoxification pathways of $\mathrm{SO}_{4}^{2-}$ reducers or $\mathrm{NO}_{3}^{-}$reducers (Nancharaiah and Lens, 2015). Unspecific detoxification pathways pertain to the use of non-Se specific reductases in other microorganisms, i.e. $\mathrm{SO}_{4}^{2-}, \mathrm{NO}_{3}^{-}$or $\mathrm{NO}_{2}^{-}$reductases for $\mathrm{SeO}_{4}^{2-}$ 
reduction (Lenz et al., 2009; Tucker et al., 1998). On the other hand, recent studies on the metal adsorption properties of EPS showed that under acidic conditions, bacteria-associated EPS might control anion and metal binding through reactive functional groups (d'Abzac et al., 2013). This was observed by Kenward et al. (2006), where Shewanella putrefaciens sorbed $\mathrm{SeO}_{4}^{2-}$ to its cell wall optimally at $\mathrm{pH} 3$. Sorbed $\mathrm{SeO}_{4}^{2-}$ was then reduced to $\mathrm{Se}^{0}$ from within the cell by an intracellular electron donor, presumably ubiquinone. Further studies are required related to the microbial sorption and role of $\mathrm{EPS}$ in $\mathrm{SeO}_{4}^{2-}$ reduction at different $\mathrm{pH}$ values in the presence of $\mathrm{NO}_{3}^{-}$and $\mathrm{SO}_{4}^{2-}$ to fully decipher the Se removal mechanisms.

Though the influent $\mathrm{pH}$ was at 5.0, the system was always able to neutralize the incoming low $\mathrm{pH}$ to an effluent $\mathrm{pH}$ of $>7.0$. This is most likely due to both the reactor re-circulation and the ongoing denitrification and sulfate reduction processes that generate alkalinity and, therefore, neutralize the $\mathrm{pH}$ during reactor operation (Koschorreck and Tittel, 2007; Nancharaiah et al., 2017; Shen et al., 2013). Alkalinity produced during denitrification and $\mathrm{SO}_{4}^{2-}$ reduction processes were estimated to be approximately $188( \pm 30) \mathrm{mg}$ $\mathrm{CaCO}_{3} \mathrm{~L}^{-1}$ (Fig. S5).

$\mathrm{NO}_{3}^{-}$removal was high and stable during phase I which lasted for 169 days. During this period, removal of $\mathrm{NO}_{3}^{-}$was associated with nitrite concentrations $<1 \mathrm{mg} \mathrm{NO}--\mathrm{N} \mathrm{L}^{-1}$ (Fig. S6). However, $\mathrm{NO}_{3}^{-}$removal became unstable in phases II and III coinciding with higher nitrite concentrations in the effluent reaching up to $3 \mathrm{mg}$ $\mathrm{NO}_{2}^{-}-\mathrm{N} \mathrm{L}^{-1}$. Low $\mathrm{pH}$ values have been suggested to hinder or even inhibit denitrification because of nitrite accumulation (Nancharaiah et al., 2017; Shen et al., 2013). Nitrite at low pH can exist as nitrous acid and has been shown to inhibit denitrification activity at a concentration as low as $0.04 \mathrm{mg} \mathrm{NO}-\mathrm{N} \mathrm{L}^{-1}$ (Baeseman et al., 2006). Shen et al. (2013) observed an approximately 28\% decrease in denitrification rates when the initial $\mathrm{pH}$ was gradually lowered to 4.5 from 7.2. Similarly, Nancharaiah et al. (2017) observed that it took longer for complete $\mathrm{NO}_{3}^{-}$removal to occur in a sequential batch reactor when the initial pH was lowered from 7.0 to 5.0 and 4.0. Therefore, unstable and decrease in $\mathrm{NO}_{3}^{-}$removal efficiency (by $20 \%$ ) can be due to the increase in nitrite levels from approximately 0.5 to $3 \mathrm{mg} \mathrm{NO}_{2}^{-}-\mathrm{N} \mathrm{L}^{-1}$ caused by the low $\mathrm{pH}$ (5.0) of the influent.

The $\mathrm{SO}_{4}^{2-}$ removal and sulfide production performance of the low influent $\mathrm{pH}$ reactor were fairly low (Fig. 1), which could be due to the presence of $\mathrm{NO}_{3}^{-}$(He and Yao, 2010) and/or the low temperature $\left(20^{\circ} \mathrm{C}\right)$ operation (Costabile et al., 2011). At pH 5.0, the $\mathrm{SO}_{4}^{2-}$ reduction was even lower, presumably because $\mathrm{SO}_{4}^{2-}$ reducers present in the Eerbeek sludge are neutrophilic (Roest et al., 2005), though there are studies on acid tolerant and acidophilic $\mathrm{SO}_{4}^{2-}$ reducers (Sánchez-Andrea et al., 2014). In contrast to this study, Lopes et al. (2008) were able to achieve nearly complete $\mathrm{SO}_{4}^{2-}$ reduction at $\mathrm{pH} 4.0$; however, the system was operated at thermophilic conditions, $\mathrm{SO}_{4}^{2-}$ was the sole electron acceptor and the organic loading rate was lower $\left(0.8-1.9 \mathrm{~g} \mathrm{COD} \mathrm{L}^{-1} \mathrm{~d}^{-1}\right)$.

\subsection{UASB reactor biomass characterization and formation}

Unlike in other UASB reactor studies conducted at low $\mathrm{pH}$ (Gonzalez-Gil et al., 2012; Lopes et al., 2008), the granular shape of the low $\mathrm{pH}$ reactor biomass was not well maintained during low $\mathrm{pH}$ UASB reactor operation (Fig. 2). The biomass growing at pH 5.0 was fluffier with filamentous structures and sticky substances surrounding the biomass, the bulk of which is likely EPS. The gradual formation of light, fluffy flocs was one of the likely causes for the floating biomass (Fig. S4a) observed during phase Ie, potentially caused by gas $\left(\mathrm{N}_{2}, \mathrm{H}_{2} \mathrm{~S}\right.$ or $\left.\mathrm{CH}_{4}\right)$ entrapped within the biomass. Loss of minerals from the low pH biomass can also contribute to the change in granular structure, though both studies at low $\mathrm{pH}$ from Gonzalez-Gil et al. (2012) and Lopes et al. (2008) maintained a granular structure despite mineral leaching ( $\mathrm{Fe}, \mathrm{Zn}, \mathrm{Cu}$ and $\mathrm{Al}$ ).

Another possible factor explaining the floating biomass from the low $\mathrm{pH}$ reactor is the polysaccharide (PS) to protein (PN) ratio (PS/ PN) of the EPS, which can affect biomass properties. Shin et al. (2000) were able to demonstrate that higher PS/PN ratios correlate with a lower negative surface charge of the biomass or higher hydrophobicity of the cells. This correlates well with the results from this study with the PS/PN ratio of the biomass in the low $\mathrm{pH}$ reactor being 15 times lower $(P$-value $\leq 0.02)$ than the PS/PN ratio of both the inoculum and the control reactor (Table 2, phase Ie). Furthermore, floating biomass was noticed less frequently during operation of the low $\mathrm{pH}$ reactor at $\mathrm{pH} 5.0$, coinciding with an increase in PS/PN ratio reaching similar values to both the inoculum and the control reactor (phase III, $P$-value $=1.0$ ). This could indicate either adaptation of the microbial community to the low $\mathrm{pH}$ conditions or a decrease in EPS production. Geyik and Çeçen (2014), for instance, observed that a lower PS/PN correlated with larger flocs of less compact biomass. These observations were attributed to the increase in hydrophobicity and cohesion between aggregates.

Another important aspect in microbial $\mathrm{SeO}_{4}^{2-}$ reduction is the immobilization of $\mathrm{Se}^{0}$ within the biomass to prevent discharge into the environment. Red deposits observed in the low $\mathrm{pH}$ granular sludge (Fig. $3 \mathrm{c} 1$ ) are strong indicators of elemental Se precipitation in the biomass. Further evidence of Se precipitation was obtained

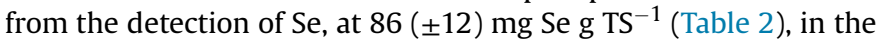
biomass and the SEM-EDX imaging analysis (Fig. 3) of the low $\mathrm{pH}$ granular sludge. The Se immobilization capacity for long-term operation of the UASB reactor at low $\mathrm{pH}$ has yet to be fully defined, despite a clear indication of $\mathrm{Se}^{0}$ entrapment within the biomass. Although there were no changes in Se removal efficiency between days 138-266 (during $\mathrm{pH} 5.0$ operation), the eventual release of $\mathrm{Se}^{0}$ can be expected due to biomass cell wall rupture/ damage (Gonzalez-Gil et al., 2016). Therefore, further studies on biogenic $\mathrm{Se}^{0}$ toxicity to biomass and $\mathrm{Se}^{0}$ retention by granular sludge in a given time frame should be conducted in order to establish the necessary frequency of biomass removal and the addition of fresh biomass.

\subsection{Microbial ecology of anaerobic granular sludge at low $p H$}

The microbial community composition changed noticeably from the inoculum (day 0 ), where the majority of the community consisted of archaeal methanogens to a bacterially-dominated diverse community mainly composed of Deltaproteobacteria and Epsilonproteobacteria. In contrast, no major changes in bacterial diversity were observed among the biomass samples taken during different phases of reactor operation.

Microorganisms capable of reducing $\mathrm{SeO}_{4}^{2-}$ are found in a wide range of phylotypes and appear to be largely related to both denitrifying and sulfate-reducing bacteria (Nancharaiah and Lens, 2015). Families of Campylobacteraceae and Desulfomicrobiaceae were dominant and consistently found in the Se removing granular sludge (Fig. 3). Additionally, analysis at the genus level (Fig. S7) indicated that the population shifted from predominantly known methanogenic to denitrifying and sulfidogenic ( $\mathrm{SO}_{4}^{2-}$ reducing) community members. This was evident by the increase in relative abundance of Sulfospirillum gen. (belonging to the Campylobacteraceae family), followed by Aminivibrio gen. (belonging to the Synergistaceae family), Desulfomicrobium gen. and Desulfovibrio gen. (both belonging to the Desulfomicrobiaceae family). These genera are not only recognized as denitrifiers, e.g. Sulfospirillum barnesii, and $\mathrm{SO}_{4}^{2-}$ reducers, e.g. Desulfovibrio desulfuricans, but have also been reported to reduce $\mathrm{SeO}_{4}^{2-}$ along with $\mathrm{NO}_{3}^{-}$and $\mathrm{SO}_{4}^{2-}$ (Lai et al., 2016; Lenz et al., 2009; Nancharaiah and Lens, 2015; OntiverosValencia et al., 2016; Tomei et al., 1995; Truong et al., 2013). This 
is most likely the reason for the high Se removal efficiencies noticed in phases Ia to Id before low pH 5.0 impacted the reactor performance. Moreover, the dominant phyla were Proteobacteria and Synergistestes which have many known denitrifying bacteria representatives that can explain the high $\mathrm{NO}_{3}^{-}$removal efficiencies $(>70 \%)$ attained throughout the low $\mathrm{pH}$ reactor operation. In addition, low $\mathrm{SO}_{4}^{2-}$ removal efficiencies (>30\%) noticed during the entire reactor operation could be due to the lower abundance of $\mathrm{SO}_{4}^{2-}$ reducers in the granular sludge.

Interesting to note was the increase of Spirochaetaceae and Geobacteraceae when operating at $\mathrm{pH}$ 5.0. The various species of Geobacteraceae are well-known to be metal reducers, including $\mathrm{SeO}_{3}^{2-}$ (Nancharaiah and Lens, 2015; Pearce et al., 2009), at circumneutral pH. In this study, the enrichment of Geobacteraceae was only observed after the $\mathrm{pH}$ was decreased to approximately 5.0. Correspondingly, Geobacteraceae-related sequences have been identified abundantly in an acidic mine lake at pH 5.5-5.9 (Lu et al., 2013). Likewise, the family Spirochaetaceae was found to be one of the dominant phylotypes in an acidic (Sánchez-Andrea et al., 2014) as well as a $\mathrm{NO}_{3}^{-}$and $\mathrm{SO}_{4}^{2-}$ rich (Liao et al., 2014) system. There are, however, thus far, no reports on Se oxyanion reduction by Spirochaetaceae.

Further studies regarding changes in microbial community structure at low $\mathrm{pH}$ are interesting to pursue, particularly during the start-up operation of the UASB reactor. In order to avoid a $\mathrm{pH}$ shock to the system, gradual lowering of the operational $\mathrm{pH}$ was employed in this study and therefore it took more than 100 days before the reactor was operated at $\mathrm{pH}$ 5.0. Using sludge bioaugmentation with Geobacteraceae and Spirochaetaceae, it might be possible to accelerate reactor start-up at pH 5.0 without major concerns for reactor failure due to high acidity.

\subsection{Industrial implications}

This study indicates the possibility of treating acidic Se-laden wastewater directly in a bioreactor without the additional cost of pre-treatment for wastewater neutralization. Assuming a wastewater treatment capacity of $15,000 \mathrm{~m}^{3}$ per day and caustic soda cost of $\$ 0.44$ per $\mathrm{kg}$, the cost of increasing the $\mathrm{pH}$ of a wastewater from 4 to 5 , using $30 \%$ caustic solution, would be approximately $\$ 35$ per day, compared to $\$ 39$ per day when increasing the $\mathrm{pH}$ to 7. It might be possible to further lower the $\mathrm{pH}$ adjustment cost, depending on the load of acidic Se-laden wastewater, by increasing the HRT (e.g. by increasing the reactor volume or decreasing the influent flow rate).

There are many aspects that need further investigation in order to further improve the understanding of reactor operations at low $\mathrm{pH}$ values. Exploration of possible changes in reactor design or operation should be considered to evaluate the optimal removal performance of Se operated at low $\mathrm{pH}$ with exposure to the coelectron acceptors $\mathrm{NO}_{3}^{-}$and $\mathrm{SO}_{4}^{2-}$. Changes in reactor operation that can be explored to increase the Se removal performance of a bioreactor are: (a) reactor configuration, e.g. promoting a biofilmdominated system as described in Ontiveros-Valencia et al. (2016); (b) increasing reactor temperature (Dessì et al., 2016); or (c) varying $\mathrm{NO}_{3}^{-}$and $\mathrm{SO}_{4}^{2-}$ concentrations (Tan et al., 2018).

A techno-economical assessment of the treatment process should be conducted to assess whether Se removal at low $\mathrm{pH}$ values would be competitive with $\mathrm{pH}$ adjustment of acidic Sewastewaters. Establishing the granular sludge Se retention capacity of a UASB reactor over time to prevent a sudden Se release potentially caused by biomass lysis (Gonzalez-Gil et al., 2016) would be an important aspect of this assessment. Another aspect to consider is the long-term Se toxicity to the biomass and microbial stress caused by low pH exposure. Working knowledge regarding the biomass stress response would be useful in order to establish a proper biomass removal cycle and the frequency of fresh biomass addition.

\section{Conclusions}

UASB bioreactor performance for the removal of $\mathrm{SeO}_{4}^{2-}, \mathrm{SO}_{4}^{2-}$ and $\mathrm{NO}_{3}^{-}$using lactate as the electron donor at $20^{\circ} \mathrm{C}$ and at $\mathrm{pH}$ values between 7.0 and 5.0 was investigated over 266 days. Upon operation of the UASB reactor at influent $\mathrm{pH} 5.0$, the reactor performance showed a trend of $20-30 \%$ decrease, achieving a Se $\mathrm{Stal}_{\text {tol }}$ and $\mathrm{Se}_{\text {diss }}$ removal efficiency of $43( \pm 13) \%$ and $61( \pm 17) \%$. A higher removal efficiency was achieved for $\mathrm{NO}_{3}^{-}(>70 \%)$, while $\mathrm{SO}_{4}^{2-}$ removal efficiencies were lower than $50 \%$ for all $\mathrm{pH}$ values investigated. Long-term reactor performance and stability could not be completely assessed at $\mathrm{pH} 5.0$ operation and as such, longer-term studies would be required for future experiments. The biomass which developed at pH 5.0 consisted of large, fluffy and filamentous granules. Microbial community analysis showed a shift from a dominantly archaeal methanogenic population in the inoculum to a bacterially dominated community during reactor operation. The bacterial community in the reactor was mainly composed of known denitrifiers and $\mathrm{SO}_{4}^{2-}$ reducers, i.e. Sulfospirillum and Desulfovibrio. An enrichment of Geobacteraceae and Spirochaetaceae was observed once the reactor was operated at $\mathrm{pH}$ 5.0.

\section{Acknowledgments}

The authors would like to thank Dr. Chiachi Hwang (CBE-MSU, USA) for carrying out clean-up and Illumina MiSeq analysis of biomass samples, Dr. Markus Dieser (CBE-MSU, USA) for assistance in Mothur bioinformatics coding, and Neerja Zambare (CBE-MSU, USA) for assistance in SEM-EDX imaging analysis of biomass samples.

\section{Appendix A. Supplementary data}

Supplementary data related to this article can be found at https://doi.org/10.1016/j.chemosphere.2018.07.079.

\section{Funding sources}

This research was supported through the Erasmus Mundus Joint Doctorate Environmental Technologies for Contaminated Solids, Soils, and Sediments $\left(\mathrm{ETeCoS}^{3}\right)$ program (FPA n $\left.{ }^{\circ} 2010-0009\right)$, the EU Marie Curie International Incoming Fellowship (MC-IIF) Role of biofilm-matrix components in the extracellular reduction and recovery of chalcogens (BioMatch project No. 103922), the National Science Foundation (CHE-1230632) and the (State of Montana contract no.51040-MUSRI2015-05).

\section{References}

Albalasmeh, A.A., Berhe, A.A., Ghezzehei, T.A., 2013. A new method for rapid determination of polysaccharide and total carbon concentrations using UV spectrophotometry. Carbohydr. Polym. 97, 253-261. https://doi.org/10.1016/ j.carbpol.2013.04.072.

APHA, 2005. Standard Methods for Examination of Water and Wastewater, fifth ed American Public Health Association, Washington, DC, USA.

Aslanzadeh, S., Rajendran, K., Jeihanipour, A., Taherzadeh, M., 2013. The effect of effluent recirculation in a semi-continuous two-stage anaerobic digestion system. Energies 6, 2966-2981. https://doi.org/10.3390/en6062966.

Baeseman, J.L., Smith, R.L., Silverstein, J., 2006. Denitrification potential in stream sediments impacted by acid mine drainage: effects of $\mathrm{pH}$, various electron donors, and iron. Microb. Ecol. 51, 232-241. https://doi.org/10.1007/s00248005-5155-

Chung, J., Nerenberg, R., Rittmann, B.E., 2006. Bioreduction of selenate using a hydrogen-based membrane biofilm reactor. Environ. Sci. Technol. 40, 
1664-1671.

Costabile, A.L., Canto, C.S., Ratusznei, S.M., Rodrigues, J.A., Zaiat, M., Foresti, E., 2011 Temperature and feed strategy effects on sulfate and organic matter removal in an AnSBB. J. Environ. Manag. 92, 1714-1723. https://doi.org/10.1016/ j.jenvman.2011.02.001.

Dessì, P., Jain, R., Singh, S., Seder-Colomina, M., van Hullebusch, E.D., Rene, E.R., Ahammad, S.Z., Carucci, A., Lens, P.N.L., 2016. Effect of temperature on selenium removal from wastewater by UASB reactors. Water Res. 94, 146-154. https:/ doi.org/10.1016/j.watres.2016.02.007.

d'Abzac, P., Bordas, F., Joussein, E., van Hullebusch, E.D., Lens, P.N.L., Guibaud, G., 2013. Metal binding properties of extracellular polymeric substances extracted from anaerobic granular sludges. Environ. Sci. Pollut. Res. Int. 20, 4509-4519. https://doi.org/10.1007/s11356-012-1401-3.

Erosa, D., Höll, W.H., Horst, J., 2009. Sorption of selenium species onto weakly basic anion exchangers: I. Equilibrium studies. React. Funct. Polym. 69, 576-585. https://doi.org/10.1016/j.reactfunctpolym.2009.03.013.

Espinosa-Ortiz, E.J., Rene, E.R., van Hullebusch, E.D., Lens, P.N.L., 2015. Removal of selenite from wastewater in a Phanerochaete chrysosporium pellet based funga bioreactor. Int. Biodeterior. Biodegrad. 102, 361-369. https://doi.org/10.1016 j.ibiod.2015.04.014.

Geyik, A.G., Çeçen, F., 2014. Production of protein- and polysaccharide-EPS in activated sludge reactors operated at different carbon to nitrogen ratios. J. Chem. Technol. Biotechnol. 91, 522-531. https://doi.org/10.1002/jctb.4608.

Gonzalez-Gil, G., Lopes, S.I.C., Saikaly, P.E., Lens, P.N.L., 2012. Leaching and accumulation of trace elements in sulfate reducing granular sludge under concomitant thermophilic and low pH conditions. Bioresour. Technol. 126, 238-246. https://doi.org/10.1016/j.biortech.2012.09.044.

Gonzalez-Gil, G., Lens, P.N.L., Saikaly, P.E., 2016. Selenite reduction by anaerobic microbial aggregates: microbial community structure, and proteins associated to the produced selenium spheres. Front. Microbiol. 7, 571. https://doi.org/ 10.3389/fmicb.2016.00571.

He, Q., Yao, K., 2010. Microbial reduction of selenium oxyanions by Anaeromyxobacter dehalogenans. Bioresour. Technol. 101, 3760-3764. https://doi.org 10.1016/j.biortech.2009.12.065.

Jain, R., Seder-Colomina, M., Jordan, N., Dessi, P., Cosmidis, J., van Hullebusch, E.D. Weiss, S., Farges, F., Lens, P.N.L., 2015. Entrapped elemental selenium nanoparticles affect physicochemical properties of selenium fed activated sludge. J. Hazard Mater. 295, 193-200. https://doi.org/10.1016/j.jhazmat.2015.03.043.

Jain, R., Matassa, S., Singh, S., van Hullebusch, E.D., Esposito, G., Lens, P.N.L., 2016 Reduction of selenite to elemental selenium nanoparticles by activated sludge. Environ. Sci. Pollut. Res. 23, 1193-1202. https://doi.org/10.1007/s11356-015 5138-7.

Jain, R., Jordan, N., Tsushima, S., Hübner, R., Weiss, S., Lens, P.N.L., 2017. Shape change of biogenic elemental selenium nanoparticles from nanospheres to nanorods decreases their colloidal stability. Environ. Sci. Nano 4, 1054-1063. https://doi.org/10.1039/C7EN00145B.

Kenward, P.A., Fowle, D.A., Yee, N., 2006. Microbial selenate sorption and reduction in nutrient limited systems. Environ. Sci. Technol. 40, 3782-3786.

Koschorreck, M., Tittel, J., 2007. Natural alkalinity generation in neutral lakes affected by acid mine drainage. J. Environ. Qual. 36, 1163-1171. https://doi.org/ 10.2134/jeq2006.0354.

Lai, C.-Y., Wen, L.-L., Shi, L.-D., Zhao, K.-K., Wang, Y.-Q., Yang, X., Rittman, B.E., Zhou, C., Tang, Y., Zheng, P., Zhao, H.-P., 2016. Selenate and nitrate bioreduction using methane as the electron donor in a membrane biofilm reactor. Environ. Sci. Technol. 50, 10179-10186. https://doi.org/10.1021/acs.est.6b02807.

Lemly, A.D., 2014. Teratogenic effects and monetary cost of selenium poisoning of fish in Lake Sutton, North Carolina. Ecotoxicol. Environ. Saf. 104, 160-167.

Lenz, M., van Hullebusch, E.D., Hommes, G., Corvini, P.F., Lens, P.N.L., 2008. Selenate removal in methanogenic and sulfate-reducing upflow anaerobic sludge bed reactors. Water Res. 42, 2184-2194. https://doi.org/10.1016/ j.watres.2007.11.031.

Lenz, M., Enright, A.M., O'Flaherty, V., van Aelst, A.C., Lens, P.N.L., 2009. Bioaugmentation of UASB reactors with immobilized Sulfurospirillum barnesii for simultaneous selenate and nitrate removal. Appl. Microbiol. Biotechnol. 83, 377-388. https://doi.org/10.1007/s00253-009-1915-X.

Li, D.B., Cheng, Y.Y., Wu, C., Li, W.W., Li, N., Yang, Z.C., Tong, Z.H., Yu, H.Q., 2014 Selenite reduction by Shewanella oneidensis MR-1 is mediated by fumarate reductase in periplasm. Sci. Rep. 4, 3735. https://doi.org/10.1038/srep03735.

Liao, R., Li, Y, Yu, X., Shi, P. Wang Z., Shen, K., Shi, Q, Miao, Y, Li, W., Li, A, 2014. Performance and microbial diversity of an expanded granular sludge bed reactor for high sulfate and nitrate waste brine treatment. J. Environ. Sci. 26 717-725. https://doi.org/10.1016/S1001-0742(13)60479-9.

Lopes, S.I., Capela, M.I., Dar, S.A., Muyzer, G., Lens, P.N.L., 2008. Sulfate reduction at $\mathrm{pH} 4$ during the thermophilic $\left(55^{\circ} \mathrm{C}\right)$ acidification of sucrose in UASB reactors. Biotechnol. Prog. 24, 1278-1289. https://doi.org/10.1021/bp.61.
Lu, S., Chourey, K., Reiche, M., Nietzsche, S., Shah, M.B., Neu, T.R., Hettich, R.L., Küsel, K., 2013. Insights into the structure and metabolic function of microbes that shape pelagic iron-rich aggregates ("Iron Snow"). Appl. Environ. Microbiol. 79, 4272-4281. https://doi.org/10.1128/AEM.00467-13.

Lueders, T., Manefield, M., Friedrich, M.W., 2004. Enhanced sensitivity of DNA- and rRNA-based stable isotope probing by fractionation and quantitative analysis of isopycnic centrifugation gradients. Environ. Microbiol. 6, 73-78. https:// doi.org/10.1046/j.1462-2920.2003.00536.x.

Nancharaiah, Y.V., Lens, P.N.L., 2015. The ecology and biotechnology of seleniumrespiring bacteria. Microbiol. Mol. Biol. Rev. 79, 61-80. https://doi.org/ 10.1128/MMBR.00037-14.

Nancharaiah, Y.V., Krishna Mohan, T.V., Satya Sai, P.M., Venugopalan, V.P., 2017. Denitrification of high strength nitrate bearing acidic waters in granular sludge sequencing batch reactors. Int. Biodeterior. Biodegrad. 119, 28-36. https:// doi.org/10.1016/j.ibiod.2016.10.057.

Ontiveros-Valencia, A., Penton, C.R., Krajmalnik-Brown, R., Rittmann, B.E., 2016 Hydrogen-fed biofilm reactors reducing selenate and sulfate: community structure and capture of elemental selenium within the biofilm. Biotechnol. Bioeng. 113, 1736-1744. https://doi.org/10.1002/bit.25945.

Oremland, R.S., Herbel, M.J., Blum, J.S., Langley, S., Beveridge, T.J., Ajayan, P.M. Sutto, T., Ellis, A.V., Curran, S., 2004. Structural and spectral features of selenium nanospheres produced by Se-respiring bacteria. Appl. Environ. Microbiol. 70, 52-60. https://doi.org/10.1128/AEM.70.1.52-60.2004.

Pearce, C.I., Pattrick, R.A., Law, N., Charnock, J.M., Coker, V.S., Fellowes, J.W., Oremland, R.S., Lloyd, J.R., 2009. Investigating different mechanisms for biogenic selenite transformations: Geobacter sulfurreducens, Shewanella oneidensis and Veillonella atypica. Environ. Technol. 30,1313-1326. https://doi.org/ $10.1080 / 09593330902984751$.

Roest, K., Heilig, H.G., Smidt, H., de Vos, W.M., Stams, A.J., Akkermans, A.D., 2005. Community analysis of a full-scale anaerobic bioreactor treating paper mill wastewater. Syst. Appl. Microbiol. 28, 175-185.

Sánchez-Andrea, I., Sanz, J.L., Bijmans, M.F., Stams, A.J., 2014. Sulfate reduction at low pH to remediate acid mine drainage. J. Hazard Mater. 269, 98-109. https:// doi.org/10.1016/j.jhazmat.2013.12.032.

Schloss, P.D., Westcott, S.L., Ryabin, T., Hall, J.R., Hartmann, M., Hollister, E.B., Lesniewski, R.A., Oakley, B.B., Parks, D.H., Robinson, C.J., Sahl, J.W., Stres, B., Thallinger, G.G., Van Horn, D.J., Weber, C.F., 2009. Introducing mothur: opensource, platform-independent, community-supported software for describing and comparing microbial communities. Appl. Environ. Microbiol. 75, 7537-7541. https://doi.org/10.1128/AEM.01541-09.

Shen, Z., Zhou, Y., Hu, J., Wang, J., 2013. Denitrification performance and microbial diversity in a packed-bed bioreactor using biodegradable polymer as carbon source and biofilm support. J. Hazard Mater. 250-251, 431-438. https://doi.org/ 10.1016/j.jhazmat.2013.02.026.

Shin, H.S., Kang, S., Nam, S.T., 2000. Effect of polysaccharides to protein ratio in EPS on sludge settling characteristics. Biotechnol. Bioproc. Eng. 5, 460-464.

Soda, S., Kashiwa, M., Kagami, T., Kuroda, M., Yamashita, M., Ike, M., 2011. Laboratory-scale bioreactors for soluble selenium removal from selenium refinery wastewater using anaerobic sludge. Desalination 279, 433-438. https://doi.org/ 10.1016/j.desal.2011.06.031.

Stams, A.J.M., Grolle, K.C.F., Frijters, C.T.M., van Lier, J.B., 1992. Enrichment of thermophilic propionate-oxidizing bacteria in syntrophy with Methanobacterium thermoautotrophicum or Methanobacterium thermoformicicum. Appl. Environ. Microbiol. 58, 346-352.

Takahashi, S., Tomita, J., Nishioka, K., Hisada, T., Nishijima, M., 2014. Development of a prokaryotic universal primer for simultaneous analysis of Bacteria and Archaea using next-generation sequencing. PLoS One 9, e105592. https:// doi.org/10.1371/journal.pone.0105592.

Tan, L.C., Nancharaiah, Y.V., van Hullebusch, E.D., Lens, P.N.L., 2016. Selenium: Environmental significance, pollution, and biological treatment technologies. Biotechnol. Adv. 34, 886-907. https://doi.org/10.1017/CBO9781107415324.004.

Tan, L. . Nancharaiah, Y.V., van Hullebusch, E.D., Lens, P.N.L., 2018. Effect of elevated nitrate and sulfate concentration on selenate removal by mesophilic anaerobic granular sludge bed reactors. Environ. Sci. Water Res. Technol. 4, 303-314. https://doi.org/10.1039/C7EW00307B.

Tomei, F.A., Barton, L.L., Lemanski, C.L., Zocco, T.G., Fink, N.H., Sillerud, L.O., 1995. Transformation of selenate and selenite to elemental selenium by Desulfovibrio desulfuricans. J. Ind. Microbiol. 14, 329-336.

Truong H.YT. Chen, Y.W. Belzile, N., 2013. Effect of sulfide, selenite and mercuric mercury on the growth and methylation capacity of the sulfate reducing bacterium Desulfovibrio desulfuricans. Sci. Total Environ. 449, 373-384. https:// doi.org/10.1016/j.scitotenv.2013.01.054.

Tucker, M.D., Barton, L.L., Thomson, B.M., 1998. Reduction of $\mathrm{Cr}$, Mo, Se and U by Desulfovibrio desulfuricans immobilized in polyacrylaminde gels. J. Ind. Microbiol. Biotechnol. 20, 13-19. 